\title{
Aspergillus niveus Blochwitz 4128URM: New Source for Inulinase Production
}

\author{
Cristina Maria de Souza-Motta ${ }^{1}$, Maria Auxiliadora de Queiroz Cavalcanti $^{1 *}$, Ana Lúcia \\ Figueiredo Porto $^{2,3}$, Keila Aparecida Moreira ${ }^{2}$ and José Luiz de Lima Filho ${ }^{2,4}$ \\ ${ }^{I}$ Departamento de Micologia; Universidade Federal de Pernambuco; Av. Prof. Nelson Chaves s $/ n^{\circ}$; 50670-420; Recife - \\ PE - Brazil; ${ }^{2}$ Laboratório de Imunopatolologia Keizo Asami; Universidade Federal de Pernambuco; Av. Professor \\ Moraes do Rego, 1235, Cidade Universitária; 50670-901; Recife -PE - Brazil; ${ }^{3}$ Departamento de Morfologia e \\ Fisiologia Animal; Universidade Federal Rural Pernambuco; ${ }^{4}$ Departamento de Bioquímica; Universidade \\ Federal de Pernambuco; Av. Prof. Nelson Chaves s $n^{\circ}$; 50670-420; Recife -PE - Brazil
}

\begin{abstract}
Aspergillus niveus Blochwitz 4128 URM isolated from sunflower rhizosphere demonstrated a new source of inulinase. The enzyme was produced in culture medium containing inulin as substrate in the concentrations: 10, 15 and $20 \mathrm{~g} \mathrm{~L}^{-1}$. Maximum enzyme activity was obtained in medium containing $20 \mathrm{~g} \mathrm{~L}^{-1}$ inulin. The enzyme was partially purified using ammonium sulphate precipitation, followed by ion charge (DE-32) and molecular exclusion (Sephadex) chromatography. The results showed the optimal $\mathrm{pH}$ and temperature of inulinase from crude extract were 4.0 and 4.8 and $45^{\circ} \mathrm{C}$, respectively. The enzyme was purified 34.65 fold with yield of $53.63 \%$. A . niveus $4128 U R M$ can be used in the inulinase production with use in the food industries.
\end{abstract}

Key words: Aspergillus niveus, rhizosphere, inulinase, inulin, purification

\section{INTRODUCTION}

Inulinase (2,1-b-D-fructanohydrolases EC 3.2.1.7) hydrolyses inulin into practically pure fructose, being an excellent alternative for the production of fructose syrup (Vandamme and Derycke, 1983; Bajpai and Margaritis, 1985; Fuchs et al., 1985). Fructose formation from inulin offers advantage as it involves only a single enzymatic step yielding up to $95 \%$ fructose (Vandamme and Derycke, 1983; Pandey et al., 1999). Inulinases of many microorganisms, especially of filamentous fungi, are used to optimize process of hydrolysis of the inulin related to food industries for the production of alcohol, acetone and butanol (Zittan, 1981; Vandamme and Derycke, 1983; Pandey et al.,
1999); are also used in the medical area as a tool for the diagnosis of renal problems (Kuehnle et al., 1992). Inulinases can be found in higher plants (Vandamme and Derycke, 1983; Claessens et al., 1990; Kaur et al., 1992) and microorganisms as filamentous fungi, yeasts and bacteria (Vandamme and Derycke, 1983; Belamri et al., 1994; Wei et al., 1998; Kochhar et al., 1998; Pessoa Júnior and Vitolo, 1999; Kushi et al., 2000). Among the filamentous fungi, species of Aspergillus described in the literature are A. aureus, A. fischeri, A. flavus and A. nidulans (Gupta et al., 1994a), A. awamori (Zherebtsov et al., 1995), A. candidus (Kochhar et al., 1999), A. niger (Derycke and Vandamme, 1984; Ongen-Baysal et al., 1994; Wallis et al., 1997; Cruz et al., 1998; Nguyen et al., 1999),

\footnotetext{
* Author for correspondence
} 
A. oryzae (Gupta et al., 1998) and A. versicolor (Kochhar et al., 1997). Till now, however, there is no report on inulinase production from $A$. niveus. This work describes the partial characterization of new inulinase from A. niveus 4128 URM.

\section{MATERIALS AND METHODS}

\section{Microorganism}

Aspergillus niveus 4128URM was isolated from sunflower (Helianthus annus L.) rhizosphere according to Warcup (1950). The rhizosphere samples $(25 \mathrm{~g})$ were suspended in $225 \mathrm{~mL}$ of sterilized distilled water (1:10 dilution) and subsequently $10 \mathrm{~mL}$ of this suspension was added into $990 \mathrm{~mL}$ of sterilized distilled water. Petri dishes containing the Sabouraud Agar medium (Lacaz et al., 2002) plus chloranphenicol (100 mg $\left.\mathrm{L}^{-1}\right)$ and Bengal Rose $\left(50 \mathrm{mg} \mathrm{L}^{-1}\right)$ were inoculated with $1 \mathrm{~mL}$ of the 1:1000 diluted soil suspension. The plates were kept at room temperature $\left(\cong 28^{\circ} \mathrm{C}\right)$ and the growth of the colonies was accompanied up to $72 \mathrm{~h}$. Fragments of the individual colonies were transferred separately to the same medium containing $50 \mathrm{mg} \mathrm{L}^{-1}$ of chloranphenicol and the growth was accompanied for $72 \mathrm{~h}$. The strain was identified after growth on Czapek Agar (Raper and Fennel, 1975) by observing its macroscopic characteristics (colour, texture appearance and diameter of the colonies) and microscopic (microstructures), according to Raper and Fennell (1975). Aspergillus niveus 4128URM is available in the Collection of Culture Micoteca URM of the Departamento de Micologia, Centro de Ciências Biológicas, Universidade Federal de Pernambuco, Recife, Pernambuco, Brazil.

\section{Inoculum preparation}

A. niveus 4128URM was subcultured on the PDA (potato dextrose agar) and incubated at $30^{\circ} \mathrm{C}$ for $72 \mathrm{~h}$. Spores from the slants were suspended in sterile $0.85 \%$ saline containing $0.01 \%$ Tween 80 to obtain $2.0 \times 10^{6}$ spore $\mathrm{mL}^{-1}$. For all the experiments, $0.5 \mathrm{~mL}$ of this suspension was used.

\section{Biomass determination}

The mycelial mass of $A$. niveus 4128URM was collected by filtration (Whatman paper $\mathrm{N}^{\circ} 1$ ) of the culture medium. The biomass was determined after washing the mycelial mass with distilled water and dried at $105^{\circ} \mathrm{C}$ overnight until constant weight.

\section{Growth and production of extracellular inulinase}

A. niveus 4128URM was cultivated in culture medium (50mL) containing $\mathrm{NH}_{4} \mathrm{NO}_{3} 2.3 \mathrm{~g}$, $\left(\mathrm{NH}_{4}\right)_{2} \mathrm{HPO}_{4} 3.7 \mathrm{~g}, \mathrm{KH}_{2} \mathrm{PO}_{4} 1.0 \mathrm{~g}, \mathrm{MgSO}_{4} 0.5 \mathrm{~g}$, yeast extract $1.5 \mathrm{~g}$, inulin $(10 \mathrm{~g}, 15 \mathrm{~g}$ and $20 \mathrm{~g})$, $1000 \mathrm{~mL}$ of distilled water, pH 5.5 (Ongen-Baysal et al., 1994), contained in $250 \mathrm{~mL}$ Erlenmeyer flasks at $28{ }^{\circ} \mathrm{C}$ and $280 \mathrm{rpm}$ for $96 \mathrm{~h}$. After the mycelial separation by filtration, the filtrate was analysed for $\mathrm{pH}$, remaining sugar, biomass, protein and extracellular inulinase activity at each $24 \mathrm{~h}$. The remaining sugar was determined according to Miller (1959), after total acid hydrolyze of the samples using fructose as standard.

\section{Inulinase assay}

The enzymatic assays were accomplished according to Kochhar et al.(1999). Aliquots of 40 $\mu \mathrm{L}$ of crude extract were added to $160 \mu \mathrm{L}$ of the inulin solution to a final concentration of $1 \%(\mathrm{w} / \mathrm{v})$ in $0.1 \mathrm{~mol} \mathrm{~L}^{-1}$ sodium acetate buffer $(\mathrm{pH} \mathrm{4.8)}$ and incubated at $37^{\circ} \mathrm{C}$ for $5 \mathrm{~min}$. After this period, the reaction was stopped by adding $2 \mathrm{~mL}$ of 3.5 dinitrosalicylic-DNSA reagent (Miller, 1959), and reducing sugar formed in terms of fructose was assayed using fructose as standard. One unit of inulinase (U) was defined as the amount of enzyme, which produced $1 \mu \mathrm{mol} \mathrm{min}{ }^{-1}$ of fructose under the assay conditions as described above. The specific activity was defined as rate between total enzyme activity and quantity of protein in milligram in one milliliter.

\section{Effect of $\mathrm{pH}$ and temperature on inulinase activity}

The effect of $\mathrm{pH}$ on inulinase activity was investigated incubating the crude extract with inulin solutions $(1 \% \mathrm{w} / \mathrm{v})$ prepared in $0.1 \mathrm{~mol} \mathrm{~L}^{-1}$ sodium acetate buffer varying the $\mathrm{pH}$ from 3.6 to 5.6 at $37{ }^{\circ} \mathrm{C}$. The optimum temperature was determined by measuring the enzymatic activity of crude extract in inulin solutions $(1 \% \mathrm{w} / \mathrm{v})$ +prepared in $0.1 \mathrm{~mol} \mathrm{~L}^{-1}$ sodium acetate buffer, $\mathrm{pH}$ 4.8 in the temperature range $30^{\circ}$ to $60^{\circ} \mathrm{C}$. 


\section{Protein determination}

Total protein was determined according to Bradford (1976), using bovine serum albumin as protein standard.

All the assay were carried out in duplicate.

\section{Purification of inulinase}

The enzymatic extract was fractionated with different concentrations of ammonium sulphate as described by Green and Hughens (1955). The precipitate was centrifuged for $30 \mathrm{~min}$ at $15,000 \mathrm{~g}$. The supernatant was dialysed against $0.1 \mathrm{~mol} \mathrm{~L}^{-1}$ sodium acetate buffer $(\mathrm{pH} 4.8)$ for $24 \mathrm{~h}$. The dialysate was chromatographed through DEAE-52 diethylaminoethyl $\quad(5.0 \times 0.5 \mathrm{~cm}) \quad$ column equilibrated with $0.01 \mathrm{~mol} \mathrm{~L}^{-1}$ sodium acetate buffer ( $\mathrm{pH} 4.8$ ) under a flow rate of $1.5 \mathrm{~mL}^{\mathrm{min}}{ }^{-1}$. Proteins were eluted with linear gradient of $\mathrm{NaCl}$ $(0-1 \mathrm{M})$. Fractions with inulinase activity were pooled and subjected to gel filtration using a Sephadex G-75 column $(10 \times 1.5 \mathrm{~cm})$ equilibrated with $0.01 \mathrm{~mol} \mathrm{~L}^{-1}$ sodium acetate buffer ( $\left.\mathrm{pH} 4.8\right)$. Protein concentration of each fraction was estimed by absorbance reading at $280 \mathrm{~nm}$. Inulinase activity of each fraction was determined as described in the enzymatic assay.

\section{RESULTS AND DISCUSSION}

\section{Growth and production of extracellular inulinase}

Fig. 1 shows growth curves of Aspergillus niveus 4128URM at different concentrations of inulin (10, 15 and $\left.20 \mathrm{~g} \mathrm{~L}^{-1}\right)$. At 15 and $20 \mathrm{~g} \mathrm{~L}^{-1}$ inulin concentrations, the biosynthesis of inulinase occurred in log phase of the growth. Cruz et al.(1998) observed a similar behavior for A. niger 245, which showed inulinase production in the log phase between $24 \mathrm{~h}$ and $60 \mathrm{~h}$. Poorna and Kulkarni (1995) obtained, working with the same species, maximum growth in $48 \mathrm{~h}$ and maximum inulinase production in the log phase between $48 \mathrm{~h}$ and $60 \mathrm{~h}$. The inulinase production by $A$. niveus 4128URM was shown to be dependent of the inulin concentration and fermentation time. In the studied range, the maximum inulinase activity was significantly superior $(\mathrm{P}<0.05)$ at inulin concentrations of $15 \mathrm{~g} \mathrm{~L}^{-1}\left(8.71 \mathrm{U} \mathrm{mL}^{-1}\right)$ and $20 \mathrm{~g}$ $\mathrm{L}^{-1}\left(11 \mathrm{U} \mathrm{mL} \mathrm{mL}^{-1}\right)$ at $72 \mathrm{~h}$ of incubation and presented significant difference among the studied periods (0-48 $\mathrm{h}$ and 48-72 $\mathrm{h})$. However, at inulin concentration of $10 \mathrm{~g} \mathrm{~L}^{-1}$, the maximum inulinase activity was significantly lower $\left(2.63 \mathrm{U} \mathrm{mL}^{-1}\right)$ at $24 \mathrm{~h}$, showing decrease after this period probably due the diauxic phenomena presented in this concentration. Therefore, best inulin concentration for inulinase production by $A$. niveus 4128URM was $20 \mathrm{~g} \mathrm{~L}^{-1}$ after $72 \mathrm{~h}$ of incubation. This inulin concentration $\left(20 \mathrm{~g} \mathrm{~L}^{-1}\right)$ has been mentioned for inulinase production by several authors, such as, Gupta et al.(1994a) who working with A. aureus, A. fischeri, A. flavus, A. nidulans and A. niger, obtained total activity between 1.0-1.2 $\mathrm{U} \mathrm{mL}^{-1}$ after nine days; Cruz et al.(1998) obtained $2.47 \mathrm{U}$ $\mathrm{mL}^{-1}$ of inulinase produced by $A$. niger 245 after $60 \mathrm{~h}$; Gupta et al.(1998) obtained $1.2 \mathrm{U} \mathrm{mL}^{-1}$ of inulinase produced by $A$. oryzae after nine days; and Kochhar et al.(1999) who used for inulinase production, four species of Aspergillus, obtaining $0.379 \mathrm{U} \mathrm{mL}^{-1}$ for $A$. oryzae NCIM 631 after six days, $10.02 \mathrm{U} \mathrm{mL}^{-1}$ for A. candidus NCIM 88, $0.053 \mathrm{U} \mathrm{mL}^{-1}$ for A. chevalieri NCIM 940 after nine days and $0.113 \mathrm{U} \mathrm{mL}^{-1}$ for A. terreus NCIM 653 after 15 days. Ongen-Baysal et al.(1994) observed higher inulinase activity of $A$. niger A42 $\left(54 \mathrm{U} \mathrm{mL}^{-1}\right)$ in medium in which carbon source was Jerusalem artichokes extract $\left(10 \mathrm{~g} \mathrm{~L}^{-1}\right)$, but only after $192 \mathrm{~h}$ of incubation. All the authors used similar methods for determination of enzyme activity with inulin as substrate. Our results showed that the values of the maximum inulinase activity produced by $A$. niveus 4128URM were higher than referred by most of the authors.

The average comparison by Tukey test (minimum significant differences were $0.802,7.75 \mathrm{mg} \mathrm{mL}^{-1}$, $6.45 \%$ and $3.32 \mathrm{U} \mathrm{mL}^{-1}$, respectively for $\mathrm{pH}$, biomass, remaining sugar and total inulinase activity), indicated that there was not a significant difference $(\mathrm{P}<0.05)$ in the consumption of the sugar for $A$. niveus 4128URM to the used concentrations of inulin (10, 15 and $\left.20 \mathrm{~g} \mathrm{~L}^{-1}\right)$ during the fermentation. The sugar was totally consumed in $72 \mathrm{~h}$ at all tested concentrations. Related to $\mathrm{pH}$ variation, there was a significant difference in dependence of the sugar concentration. Media containing 15 and $20 \mathrm{~g}$ inulin $\mathrm{L}^{-1}$ showed higher velocity of acidification. During fermentation the $\mathrm{pH}$ decreased from 5.0 to approximately 2.5 after $96 \mathrm{~h}$. Wallis et al.(1997) reported that during the inulinase production by $A$. niger $\mathrm{N} 402$, the $\mathrm{pH}$ values decreased from 5.5 to 2.5 due to formation of organic acids. 


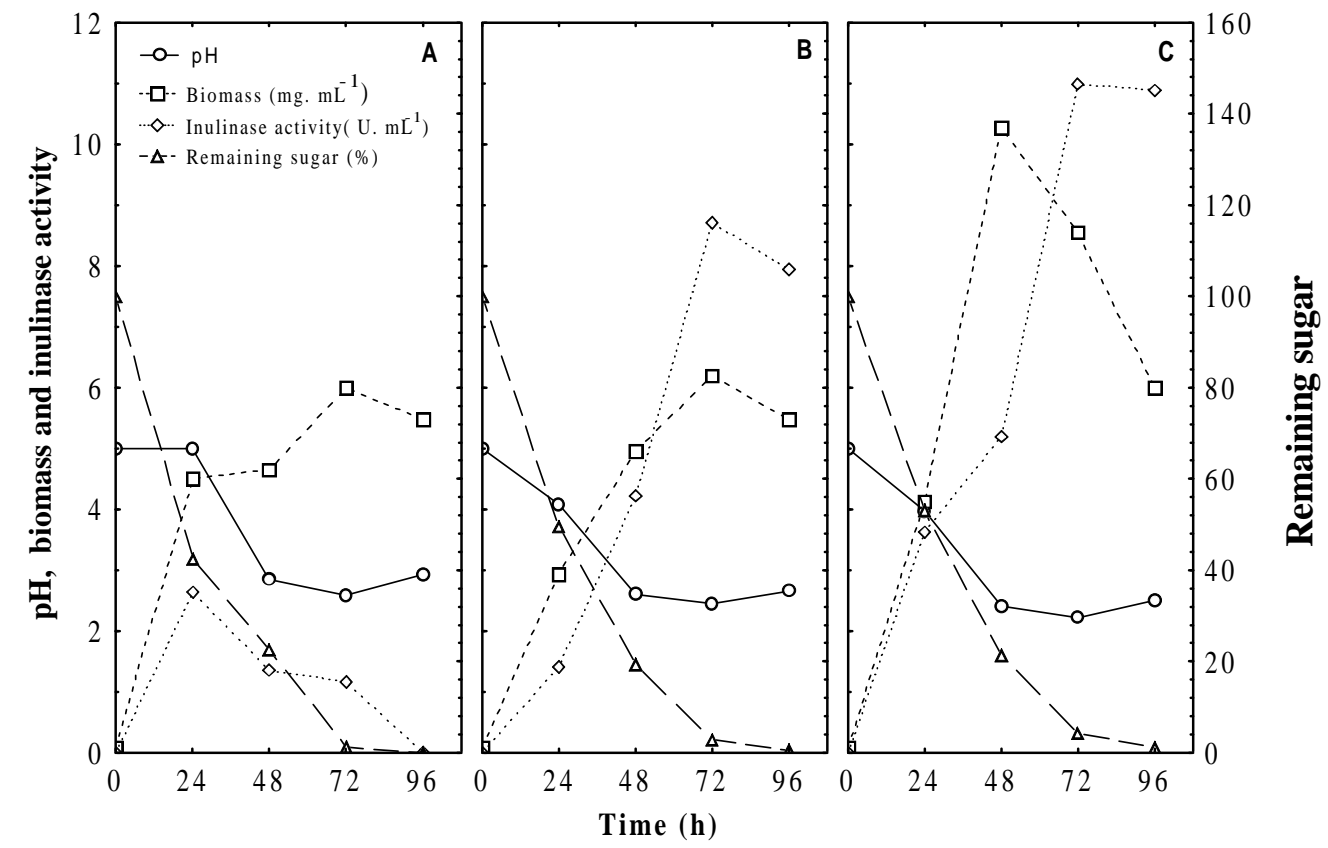

Figure 1 - pH, curves, biomass, remaining sugar and total inulinase activity of Aspergillus niveus 4128URM in medium with several inulin concentrations $\left(10,15\right.$ and $20 \mathrm{~g}$ inulin $\mathrm{L}^{-1}$ respectively for A, B and C. (Mean of two repetitions). Minimum significant differences for the Tukey test $(\mathrm{P}<0.05)$ were $0.802,7.75 \mathrm{mg} \mathrm{mL}^{-1}$.

\section{Effect of $\mathrm{pH}$ and temperature on enzymatic activity}

The effect of $\mathrm{pH}$ and temperature on the inulinase activity of A. niveus 4128URM is shown in Fig. 2. Best results were at $\mathrm{pH} 4.0$ and 4.8 and the optimum temperature was $45^{\circ} \mathrm{C}$.

The results are in accordance with Nakamura et al.(1978), Zittan (1981) and Vandamme and Derycke (1983) working with Aspergillus spp.. Best inulinase activity produced by fungi was observed at $\mathrm{pH}$ range between 4.0 and 7.0 and temperature around $45^{\circ} \mathrm{C}$ and $50^{\circ} \mathrm{C}$.Derycke and Vandamme (1984) obtained higher inulinase activity at $\mathrm{pH} 4.4$ and 4.6 at temperatures of $55^{\circ} \mathrm{C}$ and $56{ }^{\circ} \mathrm{C}$. Ongen-Baysal et al.(1994) found best results at $\mathrm{pH}$ between 5.0 and 6.0 at $50{ }^{\circ} \mathrm{C}$ and Cruz et al.(1998) at pH 4.0 to 4.5 at $60{ }^{\circ} \mathrm{C}$. Some species of Aspergillus produce inulinases with maximum activity at higher temperatures, such as A. niger 245 at $60^{\circ} \mathrm{C}$ (Cruz et al., 1998). However, temperatures above $55{ }^{\circ} \mathrm{C}$ could inactivate some inulinases produced by fungi (Vandamme and Derycke, 1983), a fact that occurred with the inulinase of A. niveus 4128URM, when incubated at $60{ }^{\circ} \mathrm{C}$.

\section{Partial purification of inulinase}

The purification steps for inulinase are given in Table 1. The fraction $0-20 \%$ presented higher inulinase activity, with recovery of the $73.8 \%$ and purification of 2.63 fold. This fraction was chromatographed through ionic exchange DEAE52 obtaining $358.33 \mathrm{U} \mathrm{mg}^{-1}$ protein and a purification of 32.78 fold (Table 1; Fig. 3).

The fractions with inulinase activity (5-11) were pooled and subjected to gel filtration using a Sephadex G-75 column and the specific activity of inulinase was determined to be $378.75 \mathrm{U} \mathrm{mg}^{-1}$ protein and a purification of 34.65 fold was achieved (Table 1; Fig. 4).

The purification reached around 32.78 fold after ionic exchange (DEAE-52) column chromatography. With Sephadex G-75 chromatography inulinase was purified 34.65 fold, yielding 53.63\% (Table 1; Fig. 3 and 4). Balayan et al .1996) reached yields of $16 \%$ and $10 \%$ of inulinase produced by Penicillium palitans $\mathrm{T}-1$ and $P$. cyclopium T-18, respectively, using ultrafiltration, ammonium sulphate precipitation (0.8\% of saturation), DE-32 Cellulose and Sephadex G-150. Kochhar et al.(1997) using precipitation with ammonium sulphate, DEAE 
Cellulose, CM Cellulose and Sephadex G 150 obtained a purification of 50 fold for inulinase of Aspergillus versicolor. Values higher than our results were mentioned by Kochhar et al.(1999) for the purification of the extracellular inulinase of Aspergillus candidus, using ammonium sulphate precipitation and DEAE Cellulose and Sephadex G-150, resulting a purification of 56 fold. Chen et al.(1997) purified the inulinase of $A$. niger using precipitation with ammonium sulphate, DEAE
Cellulose and Sephadex G-100 with 67 fold purification, in this case, however, the yield was lower $(25.5 \%)$ than obtained in the present study (53.63\%). Derycke and Vandamme (1983), Cruz et al.(1998) and Pandey et al.(1999) descried that for industrial application, inulinase showed have maximum activity at $\mathrm{pH}$ lower than 5.0 and at higher temperatures, as produced by $A$. niveus 4128URM.

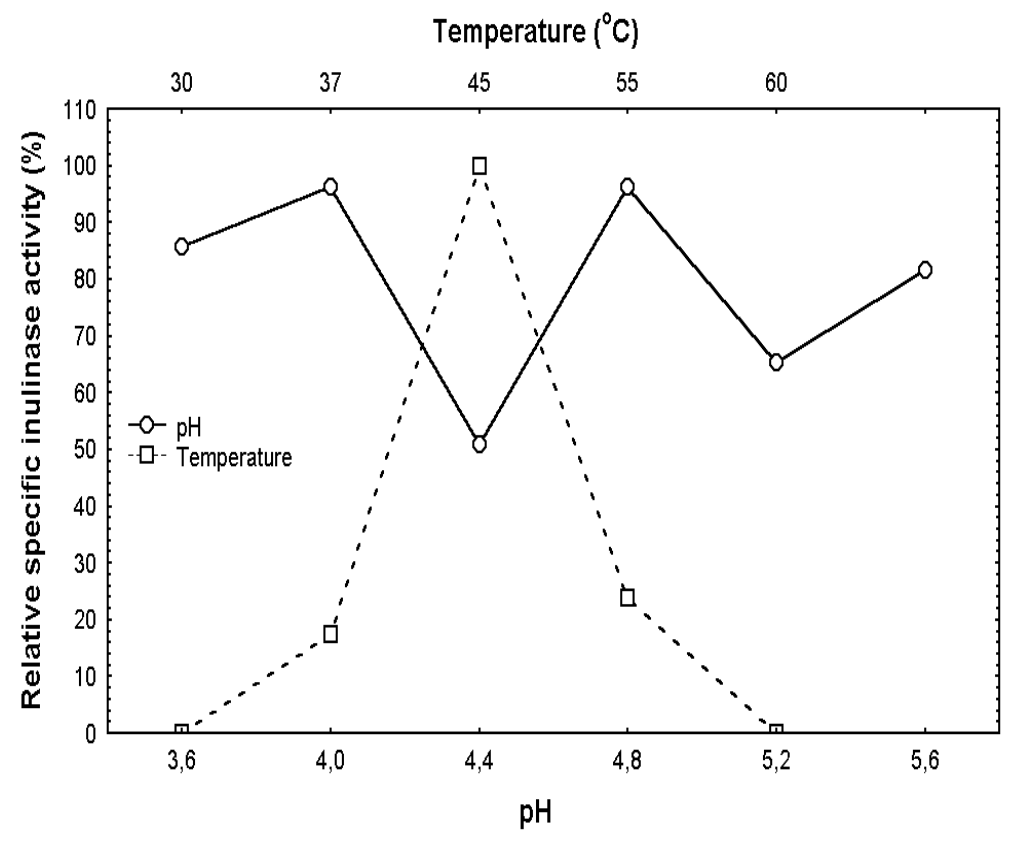

Figure 2 - Effect of $\mathrm{pH}$ and temperature on relative specific inulinase activity of Aspergillus niveus 4128URM. (Mean of two repetitions). Minimum significant differences for the Tukey test $(\mathrm{P}<0.05)$.

Table 1 - Partial purification of extracellular inulinase of A. niveus 4128URM

\begin{tabular}{|c|c|c|c|c|c|}
\hline Steps & $\begin{array}{c}\text { Total } \\
\text { protein } \\
\left(\mathrm{mg} \mathrm{ml}^{-1}\right)\end{array}$ & $\begin{array}{c}\text { Total } \\
\text { activity } \\
\left(\mathbf{U ~ m l}^{-1}\right)\end{array}$ & $\begin{array}{l}\text { Specific } \\
\text { activity } \\
\left(\mathbf{U ~ m g}^{-1}\right)\end{array}$ & $\begin{array}{l}\text { Purification } \\
\text { (folds) }\end{array}$ & $\begin{array}{l}\text { Yield } \\
(\%)\end{array}$ \\
\hline Culture filtrate & 0.517 & 5.65 & 10.93 & 1 & 100 \\
\hline Ammonium sulfate $(0-20 \%)$ & 0.145 & 4.17 & 28.76 & 2.63 & 73.80 \\
\hline DE-52 & 0.006 & 2.15 & 358.33 & 32.78 & 38.05 \\
\hline Sephadex G-75 & 0.008 & 3.03 & 378.75 & 34.65 & 53.63 \\
\hline
\end{tabular}




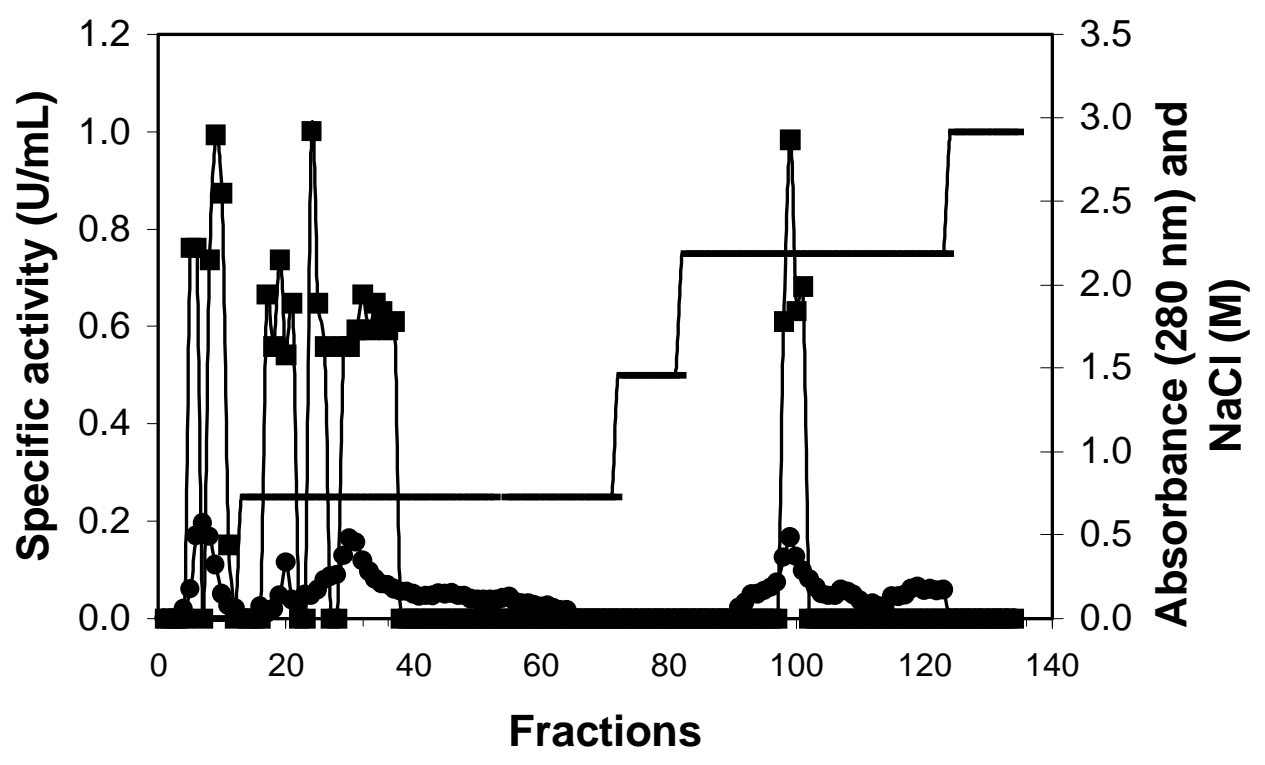

Figure 3 - Chromatography of inulinase preparation on DEAE-52 diethylaminoethyl $(5.0 \mathrm{x} 0.5 \mathrm{~cm})$ column equilibrated with $0.01 \mathrm{~mol} \mathrm{~L}^{-1}$ sodium acetate buffer $(\mathrm{pH} 4.8)$ under a flow rate of 1.5 $\mathrm{mL} \cdot \mathrm{min}^{-1}$. Proteins were eluted with linear gradient of $\mathrm{NaCl}\left(0.1 \mathrm{~mol} \mathrm{~L}^{-1}\right)$.

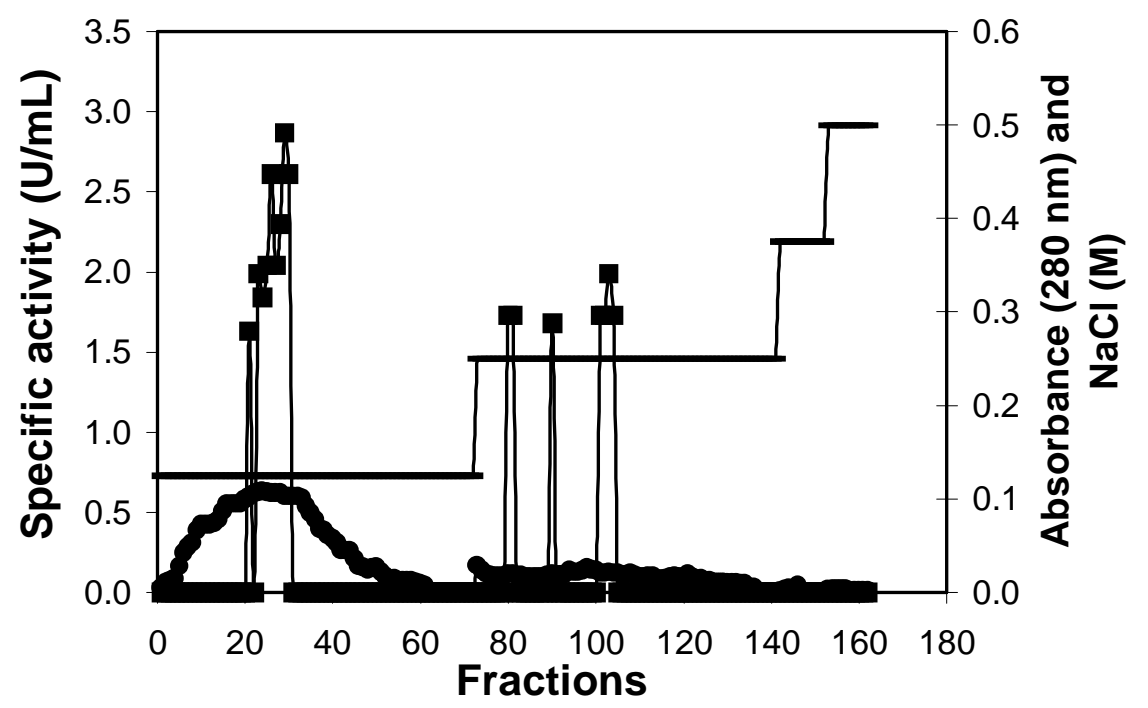

Figure 4 - Chromatography of inulinase preparation on Sephadex G-75 column $(10 \times 1.5 \mathrm{~cm})$ equilibrated with $0.01 \mathrm{~mol} \mathrm{~L}^{-1}$ sodium acetate buffer $(\mathrm{pH} 4.8)$ under a flow rate of 1.5 $\mathrm{mL} \cdot \mathrm{min}^{-1}$. 
Under these conditions bacterial contamination is rare, solubilization of inulin is favored and fructose syrup coloring is not presented. A. niveus 4128URM showed to be a promising strain for industrial production of fructose rich syrups.

\section{RESUMO}

Aspergillus niveus 4128URM isolado de rizosfera de girassol demonstrou ser uma nova fonte de inulinase. A enzima foi produzida em meio de cultura contendo inulina como substrato nas concentrações de 10,15 e $20 \mathrm{~g} \mathrm{~L}^{-1}$. Atividade máxima da enzima foi obtida em meio contendo $20 \mathrm{~g} \mathrm{~L}^{-1}$ de inulina. A enzima foi parcialmente purificada utilizando precipitação com sulfato de amônio, seguida por cromatografia de troca iônica (DE-52) e exclusão molecular (Sephadex). Os resultados mostraram o $\mathrm{pH}$ e temperatura ótima da inulinase do extrato bruto foi 4,0 e 4,8 e $45^{\circ} \mathrm{C}$, respectivamente. A enzima foi purificada 34,65 vezes com rendimento de 53,63\%. A. niveus 4128URM pode ser utilizado na produção de inulinase com perspectivas de uso na indústria de alimentos.

\section{REFERENCES}

Bajpai, P. and Margaritis, A. (1985), Immobilization of Kluyveromyces marxianus cells containing inulinase activity in open pore gelatin matrix: 2. Application for high fructose syrup production. Enzyme Microb. Technol., 7, 459-469.

Balayan, A. M.; Pivazian, L. A.; Khachaturian, R. N.; Afrikian, E. G. and Abelian, V. A. (1996), Inulinases from Penicillium palitans and Penicillium cyclopium. Biochemistry (Moscow), 61, 645-650.

Belamri, M.; Sassi, H. S.; Savart, M.; Tantaoui-Elaraki, A. and Cottin, P. (1994), Purification and properties of an extracellular inulinase-like $\beta$-fructosidase from Bacillus stearothermophilus. Lett. Appl. Microbiol., 19, 410-413.

Bradford, M. M. (1976), A rapid and sensitive method for the quantification of microgram quantities of protein utilizing the principle of Protein-Dye Binding. Anal. Biochem., 72, 248-254.

Chen, G.; Sun, Z.; Wang, Y. and Qian, X. (1997), Purification and properties of inulinase from Aspergillus niger. Weishengwu Xuebao, 37, 362-367.

Claessens, G.; Vanlaere, A. and Deproft, M. (1990), Purification and properties of an inulinase from chicory roots (Cichorium intybus L). J. Plant Physiol., 136, 35-39.
Cruz, V. D.; Belote, J. G.; Belline, M. Z. and Cruz, R. (1998), Production and action pattern of inulinase from Aspergillus niger-245: hydrolysis of inulin from several sources. Rev. Microbiol., 29, 301-306.

Derycke, D. G. and Vandame, E. J. (1984), Production and properties of Aspergillus niger inulinase. $J$. Chem. Tech. Biotechnol.., 34, 45-51.

Fuchs, A., Bruijn, J. M. and Niedeveld, C. J. (1985), Bacteria and yeast as possible candidates for

production of inulinases and levanases. Antonie Leewenhoek J. Microbiol. Serol., 51, 333-351.

Green, A. A. and Hughens, W. L. (1955), Protein fractionation on tha basis of solubility in aqueous solutions of salts and organic solvents. Methods Enzymol., 1, 67-90.

Gupta, A. K.; Gill, A.; Kaur, N. and Singh, R. (1994a), High thermal stability of inulinases from Aspergillus species. Biotechnol. Lett., 16, 733-734.

Gupta, A. K.; Singh, D. P.; Kaur, N. and Singh, R. (1994b)., Production, purification and immobilisation of inulinase from Kluyveromyces fragilis. J. Chem. Technol. Biotechnol., 59, 377-385.

Gupta, A. K.; Gill, A. and Kaur, N. (1998), A $\mathrm{HgCl}_{2}$ insensitive and thermally stable inulinase from Aspergillus oryzae. Phytochemistry, 49, 55-58.

Kaur, N.; Kaur, M.; Gupta, A. K. and Singh, R. (1992), Properties of $\beta$-fructosidases (invertases and inulinases) of Fusarium oxysporum grown on an aqueous extract of Cichorium intybus roots. J. Chem. Technol. Biotechnol., 53, 279-284.

Kochhar, A.; Kaur, N. and Gupta, A. K. (1997), Inulinase from Aspergillus versicolor: a potent enzyme for producing fructose from inulin. J. Sci. Ind. Res., 56, 721-726.

Kochhar, A.; Kaur, N. and Gupta, A. K. (1998), Immobilization of inulinase from Aspergillus versicolor for preparing fructose from inulin. J. Sci. Ind. Res., 57, 184-187.

Kochhar, A., Gupta, A. K. and Kaur, N. (1999), Purification and immobilisation of inulinase from Aspergillus candidus for producing fructose. J. Sci. Food Agri., 79, 594-554.

Kuehnle, H. F.; Von Dahl, K. and Schmidt, F. H. (1992), Fully enzymic inulin determination in small volume samples without deproteinisation. Nephron, 62, 104-107.

Kushi, R. T.; Monti, R. and Contiero, J. (2000), Production, purification and characterization of an extracellular inulinase from Kluyveromyces marxianus var. bulgaricus. J. Ind. Microbiol. Biotechnol., 25, 63-69.

Lacaz, C. S; Porto, E and Martins, J. E. (2002), Micologia médica: fungos, actinomicetos e algas de interesse médico. São Paulo : Savier.

Miller, G. L. (1959), Use of dinitrosalicylic acid for determination of reducing sugar. Anal. Chem., 31, 426-428. 
Nakamura, T.; Hoashi, S. and Nakatsu, S. (1978), Culture conditions for inulinase production by Aspergillus (Studies on microbial inulase Part III). Nippon Nogeikagaku Kaishi., 52, 105-110.

Nguyen, Q. D.; Mattes, F.; Hoschke, A.; RezessySzabo, J. and Bhat, M. K. (1999), Production, purification and identification of fructooligosaccharides produced by betafructofuranosidase from Aspergillus niger IMI303386. Biotechnol. Lett., 21, 183-186.

Ongen-Baysal, G.; Sukan, S. S. and Vassilev, N. (1994), Production and properties of inulinase from Aspergillus niger. Biotechnol. Lett., 16, 275-280.

Pandey, A.; Soccol, C. R.; Selvakumar, P.; Soccol, V. T.; Krieger, N. and Fontana, J. D. (1999), Recent developments in microbial inulinases - Its production, properties, and industrial applications. Appl. Biochem. Biotechnol., 81, 35-52.

Pessoa Júnior, A. and Vitolo, M. (1999), Inulinase from Kluyveromyces marxianus: Culture medium composition and enzyme extraction. Braz. J. Chem. Eng., 16, 237-245.

Poorna, V. and Kulkarni, P. R. (1995), A study of inulinase production in Aspergillus niger using fractional factorial design. Bioresour. Technol., 54, 315-320.

Raper, K. B. And Fenell, D. I. (1975), The genus Aspergillus. Malabar Florida : Robert and Krieger.

Vandamme, E. J. and Deryke, D. G. (1983), Microbial inulinases: fermentation process, properties and applications. Adv. Appl. Microbiol., 29, 139-176.

Warcup, J. H. (1950), The soil plate method for isolation of fungi from soil. Nature, 166, 117-150.

Wallis, G. L. F.; Hemming, F. W. and Peberdy, J. F. (1997), Secretion of two beta-fructofuranosidases by Aspergillus niger growing in sucrose. Arch. Biochem. Biophys., 345, 214-222.

Wei, W. L.; Zheng, Z. H.; Liu, Y. Y. and Zhu, X. S. (1998), Optimizing the culture conditions for higher inulinase production by Kluyveromyces sp. Y-85 and scaling-up fermentation. J. Ferment. Bioeng., 86, 395-399.

Zherebtsov, N. A.; Korneeva, O. S. and Tertychnaya, T. N. (1995), On the mechanism of splitting of $\beta-2,1-$ fructoside bonds of inulin by inulinase from Aspergillus awamori 2250. Biochemistry (Moscow), 60, 1205-1211.

Zittan, L. (1981), Enzymatic hydrolysis of inulin - an alternative way to fructose production. Starch, 33, 373-377. 